УДК 378.04:338.48

Дишко Олеся Леонідівна

кандидат педагогічних наук, доцент кафедри туризму

ПВНЗ «Академія рекреаційних технологій і права», м. Луцьк, Україна

olesya.dyshko16@gmail.com

\title{
ВИКОРИСТАННЯ ВІРТУАЛЬНИХ СПІЛЬНОТ ДЛЯ ПІДГОТОВКИ БАКЛАВРІВ 3 ТУРИЗМУ ДО ПРОФЕСІЙНОЇ ВЗАСМОДІЇ ЗІ СПОЖИВАЧАМИ ТУРИСТИЧНИХ ПОСЛУГ
}

\begin{abstract}
Анотація. У статті розглянуто систему поглядів на проблему підготовки фахівців з туризму до професійної взаємодії зі споживачами туристичних послуг за допомогою спільнот у глобальних комунікаційних мережах. Наведено результати анкетування викладачів щодо використання віртуальних спільнот для підготовки бакалаврів 3 туризму до професійної взаємодії зі споживачами туристичних послуг. Представлено результати опитування студентів-туристів щодо ефективності використання соціальних мереж у процесі навчання. Обгрунтовано доцільність створення Інтернет-клубу спілкування 3 клієнтами для практичної підготовки майбутніх фахівців до професійної взаємодії зі споживачами туристичних послуг.
\end{abstract}

Ключові слова: бакалаври з туризму; віртуальна спільнота; споживачі туристичних послуг; Інтернет-клуб спілкування з клієнтами.

\section{1. ВСТУП}

Постановка проблеми. Сучасна освіта України переживає динамічні зміни, що спрямовують вищу школу на підвищення ефективності професійної підготовки конкурентоспроможних спеціалістів. Формування замовлення на фахівців у галузі туризму передбачає орієнтацію на таких висококваліфікованих фахівців, які володіють інформаційно-комунікаційними технологіями, різнобічними і глибокими професійними знаннями і вміннями, здатні до постійного поповнення й оновлення знань для підготовки до професійної взаємодії зі споживачами туристичних послуг, що допомагає не тільки діяти, переконувати, ухвалювати рішення, а й створювати сприятливу ділову атмосферу, розуміти потреби споживачів туристичних послуг. На нашу думку, одним із засобів підготовки сучасного фахівця може бути участь студентів у спільнотах соціальних мереж, у тому числі Інтернет-клубі спілкування з клієнтами.

Аналіз останніх досліджень і публікацій. Дослідженню проблем професійної підготовки фахівців 3 туризму дослідники завжди приділяли значну увагу. Зокрема таким іï аспектам, як професійна підготовка кадрів для туристичної сфери (О. Баглай, О. Бейдик, А. Віндюк, М. Галицька, Р. Загнибіда, Г. Зайчук, Л. Козак, В. Лозовецька, О. Любіцева, М. Мальська, Л. Сакун, Т. Сокол, В. Федорченко, Н. Фоменко, Г. Цехмістрова та ін.); особливості практичної підготовки фахівців 3 туризму (А. Волкова, Л. Поважна, Н. Хмілярчук, М. Черезова, Г. Щука й ін.); психологопедагогічні проблеми спілкування й комунікації в туризмі (С. Александрова, Г. Андрєєва, Л. Грибова, Н. Кобзар, В. Лівенцова, Л. Орбан-Лембрик та ін.).

Проблему впровадження інформаційно-комунікаційних технологій у навчальний процес актуалізують у своїх дослідженнях науковці Н. Бєлікова, Р. Гуревич, І. Зимня, М. Кадемія, В. Кучеренко, Н. Морзе, М. Овчіннікова, Ю. Рамський, С. Сисоєва, А. Хуторський та ін. 
Вагомий внесок у вивчення можливостей використання віртуальних спільнот в освіті зробили Т. Архіпова, Р. Гуревич, Ю. Дюлічева, С. Литвинова, І. Малицька, М. Остапенко, І. Іванюк, А. Яцишин та ін.

Водночас аналіз фахової літератури дає підстави констатувати, що дослідження, які б безпосередньо стосувалися питання використання Інтернет-клубу спілкування 3 клієнтами для формування готовності бакалаврів $з$ туризму до професійної взаємодії зі споживачами туристичних послуг, відсутні, що зумовило актуальність нашого дослідження.

Метою статті $\epsilon$ теоретичне обгрунтування доцільності функціонування Інтернетклубу спілкування з клієнтами для підготовки бакалаврів з туризму до професійної взаємодії зі споживачами туристичних послуг.

\section{2. ТЕОРЕТИЧНІ ОСНОВИ ДОСЛІДЖЕННЯ}

У зв’язку зі стрімким розвитком інформаційно-комунікаційних технологій i значним інтересом до них студентів викладачі активно впроваджують інноваційні методики викладання, використовуючи новітні інформаційно-комунікаційні технології (ІКТ), сервіси Інтернету, віртуальні освітні (навчальні) спільноти.

Водночас, необхідно розуміти, що інтернет - це засіб і середовище існування поза суспільством, якщо суспільство розуміти, як систему інститутів. Суспільство як нормативна структура не працює в процесі комунікацій, здійснюваних через Інтернет. Попри це,, Інтернет - середовище розвитку віртуальних спільнот, альтернативних реальному суспільству. Крім того віртуалізується не тільки суспільство, але й породжена ним особистість [1, с. 145].

Дослідження показують, що в середньому доросла людина в розвиненому цифровому світі проводить за переглядом різних цифрових медіа 5,7 години на день цей показник подвоївся за останні 7 років. Активність сучасних інтернет-користувачів зосереджується навколо візуального контенту, обміну ним, класифікації і створення власного у форматі репост, фан-творчості, мемів, а також рецензій і рейтингів. Тенденції, що виявили себе на більш розвинених у цифровому відношенні територіях, зокрема в США, проявляються в Україні із запізненням на кілька років, тому в нас $є$ рік-два, щоб підготуватися до нових реалій [10].

Нині найпоширенішим засобом організації інформаційного простору у ВНЗ є віртуальні співтовариства - це сукупність зв'язків між студентами і викладачами, що мають щось загальне (спільні цілі, інтереси, погляди, зайняття, хобі, проблеми і так далі) і що здійснюють взаємодію у віртуальному просторі. Віртуальні мережеві співтовариства належать до категорії саморегульованих соціальних структур, що саморозвиваються. Загальний принцип, що визначає характер розвитку соціальної системи кіберпростору, полягає в ії прагненні забезпечити свою цілісність і підвищити ефективність комунікаційних процесів [4; 2].

Туристична сфера $є$ інформаційно насиченою, оскільки характеризується різноманітністю ділових зв'язків із партнерами, індивідуалізацією туристичних послуг, технологічним удосконаленням і високою конкуренцією. Саме віртуальні спільноти мають великий потенціал для навчання фахівців з туризму, оскільки приваблюють студентів простотою використання, технічною доступністю, можливістю самим брати участь у спілкуванні, наявністю зворотного зв'язку з учасниками спільноти.

Як відомо, перше визначення поняття «віртуальні спільноти» дав Г. Рейнгольд. Він визначає спільноти як соціальні об’єднання людей, «які виростають 3 мережі, коли група людей підтримує відкрите обговорення проблеми достатньо довгий час і робить 
це досить людяно для того, щоб сформувати мережу своїх особистих відносин у кіберпросторі» (1993р.) [7].

Різновидом віртуальної спільноти $€$ віртуальна навчальна спільнота. Вона функціонує як віртуальний соціальний простір на інформаційно-технологічній платформі, де люди, що мають спільну мету, об'єднуються для взаємодії один з одним для набуття знань та/або обміну ними [11]. І. Іванюк віртуальну навчальну спільноту розглядає передусім як «соціальне об'єднання осіб у віртуальному просторі мережі Інтернет, які мають спільні навчальні цілі, завдання, потреби та інтереси, які беруть участь в спільному обговоренні та вирішенні навчальних завдань на основі власного досвіду» [2].

Основною метою віртуальної навчальної спільноти є підвищення рівня знань учасників у межах формальної/неформальної освіти, зокрема підвищення професійної кваліфікації. Члени навчальних спільнот обмінюються між собою ресурсами, досвідом, методиками, беруть участь у заходах, притаманних цій спільноті, обговорюють професійні проблеми, наразі дотримуючись певних правил інформаційної культури.

Разом $з$ тим віртуальне співтовариство передбачає взаємозалежність учасників, які координують і погоджують свою спільну діяльність за допомогою Інтернеттехнологій. Вони розширюють свій рівень розуміння, усвідомлення, знання і досвіду. У зв'язку з цим доцільно використовувати віртуальні спільноти у навчальному процесі.

Зокрема, автори М. Мойсеєва (Росія), С. Сойферт (Швейцарія) вважають, що для віртуальних навчальних спільнот характерні:

$\checkmark$ інтенсивний комунікаційний процес, який сприяє розвитку навичок міжособистісної комунікації, збагаченню ідеями, обміну знаннями, що приводить до більш глибокого розуміння змісту навчання;

$\checkmark$ високу мотивацію навчання i розвиток почуття індивідуальної відповідальності за групову навчальну діяльність;

$\checkmark$ збагачення навчального досвіду, набуття досвіду навчання в групі та спілкування з іншими людьми, поєднання навчального й особистого досвіду у соціальному контексті;

$\checkmark$ подолання почуття самотності, ізольованості, відчуття приналежності до колективу, надання емоційної, психологічної підтримки один одному;

$\checkmark$ навчання через роботу, практику, соціально значущий експеримент;

$\checkmark$ накопичення нового знання шляхом спілкування 3 іншими на основі методики навчання у співпраці [4].

Як зазначає I. Малицька, віртуальні навчальні спільноти «формують відповідне віртуальне навчальне середовище, у якому можна створювати і використовувати різні інформаційні ресурси, навчатися, залучаючи певні технологічні інструменти». Водночас інноваційний інструментарій постійно удосконалюється, розвивається і доповнюється. Причому, процес співпраці між учасниками не має обмежень ні в часі, ні у просторі. Усім учасникам навчального процесу надається можливість полісинхронної професійної співпраці, розвитку не тільки своїх особистих навичок, підвищення рівня викладання і навчання, але й можливість свого особистого внеску у спільні наробки 3 будь-яких освітніх напрямів, набуваючи i розвиваючи ІКТ-навички, IКТкомпетентності, створюючи поступово віртуальний освітній простір у глобальному вимірі» [3].

Активне спілкування членів спільноти, їх регулярна участь у подіях спільноти, висока мотивація і спільні інтереси роблять віртуальні спільноти незамінним інструментом для навчання. Так, К. Ала-Мутка вказує на суттєві переваги впровадження віртуальних спільнот у навчання: доступ до певних знань і розробка 
нових знань, особистісне зростання й розвиток через соціалізацію, колективне виконання завдань і спільна діяльність [6].

На нашу думку, роль віртуальних спільнот також важлива для розвитку сучасного туризму: майже всі туристичні підприємства мають свої персональні сторінки, де пропонують свої послуги, наприклад, Альтан (https://vk.com/altantour), Mope турів (https://vk.com/moreturivlutsk), Наталія Тур (Макінтур) (https://vk.com/makintur), Світ подорожей (https://vk.com/svitpodorozhej), ОЛІМП-Тур (https://vk.com/olimptourternopil), Moryana Tour (https://vk.com/moryana_1), TUI Ukraine (https://vk.com/tuiukraine) та ін. Нині кількість підписників деяких віртуальних спільнот туристичних підприємств коливається від 10245 до 265243 учасників (залежно від пропонованих послуг). Активне спілкування членів спільноти, їх регулярна участь у подіях спільноти, висока мотивація і спільні інтереси роблять віртуальні спільноти незамінним інструментом для навчання, зокрема, майбутніх фахівців з туризму. Тому важливим завданням $є$ навчити студентів грамотно вести діалог з потенційними споживачами туристичних послуг, правильно подавати й обробляти інформацію, у тому числі, через віртуальні спільноти.

\section{3. МЕТОДИКА ДОСЛІДЖЕННЯ}

Теоретична складова методики дослідження передбачала вивчення відповідної літератури, а практична - проведення анкетування викладачів і студентів щодо використання віртуальних спільнот у навчальному процесі й запровадження Інтернетклубу спілкування з клієнтами.

Під час дослідження був проведений аналіз наукової, навчально-методичної фі фахової літератури щодо використання віртуальних спільнот, а також організації педагогічного процесу з використанням ІКТ у вищий школі.

Для того щоб визначити, чи використовують викладачі у навчальному процесі віртуальні спільноти в соціальних мережах для формування готовності бакалаврів 3 туризму до професійної взаємодії зі споживачами туристичних послуг було проведено анкетування 85 викладачів вищих навчальних закладів. Це 25 викладачів Тернопільського національного педагогічного університету імені Володимира Гнатюка, 14 викладачів Східноєвропейського національного університету імені Лесі Українки, 9 викладачів Київського університету туризму, економіки i права, 8 викладачів Міжнародного економіко-гуманітарного університету імені академіка Степана Дем'янчука, 20 викладачів Класичного приватного університету, 9 викладачів ПВНЗ «Академія рекреаційних технологій і права». Водночас, щоб з'ясувати, перевагу якій соціальній мережі надають студенти, було проведено опитування 369 респондентів названих вищих навчальних закладів.

Дослідження виконане у межах науково-дослідної роботи «Теоретико-методичні засади професійної підготовки фахівців в умовах інформатизації освіти» (державний реєстраційний номер 0115U 002901).

\section{4. РЕЗУЛЬТАТИ ДОСЛІДЖЕННЯ}

У сучасній українській науковій і навчально-методичній літературі використання віртуальних спільнот як складової навчально-пізнавальної діяльності студентівтуристів майже не розглядається. Що свідчить про недооцінювання їхнього освітнього потенціалу вітчизняними фахівцями.

Зауважимо, що починаючи з 2007-2008 років, в університетах США стали активно експериментувати 3 упровадженням сервісів соціальних мереж у навчальний 
процес. Уже через 2-3 роки переважна кількість навчальних закладів мала свої офіційні сторінки у Facebook, Twitter, YouTube, вважаючи цей досвід вдалим маркетинговим кроком. Почали 3'являтися онлайн спільноти викладачів і спеціалістів у галузі еLearning. Виявилося, що віртуальні соціальні мережі сприяють розвитку електронного навчання й освіти в цілому, оскільки пропонують нові технічні й методичні рішення. Переважна більшість закордонних дослідників вважає, що у справі розвитку організації і методичної підтримки електронного навчання треба орієнтуватися не на LMS, що $є$ негнучкими інструментами, а на популярні соціальні мережі [5]. На нашу думку, такий досвід необхідно враховувати.

Практичні результати нашого дослідження грунтуються на анкетуванні викладачів і студентів. Запитання анкети мали за мету дізнатися, чи використовують викладачі віртуальні спільноти для підготовки бакалаврів з туризму до професійної взаємодії з клієнтами. Анкетування виявило, що використовують спільноти 15,29 \% викладачів, не використовують - 71,76 \% опитаних; важко було відповісти - 12,95 \% респондентам (рис. 1).

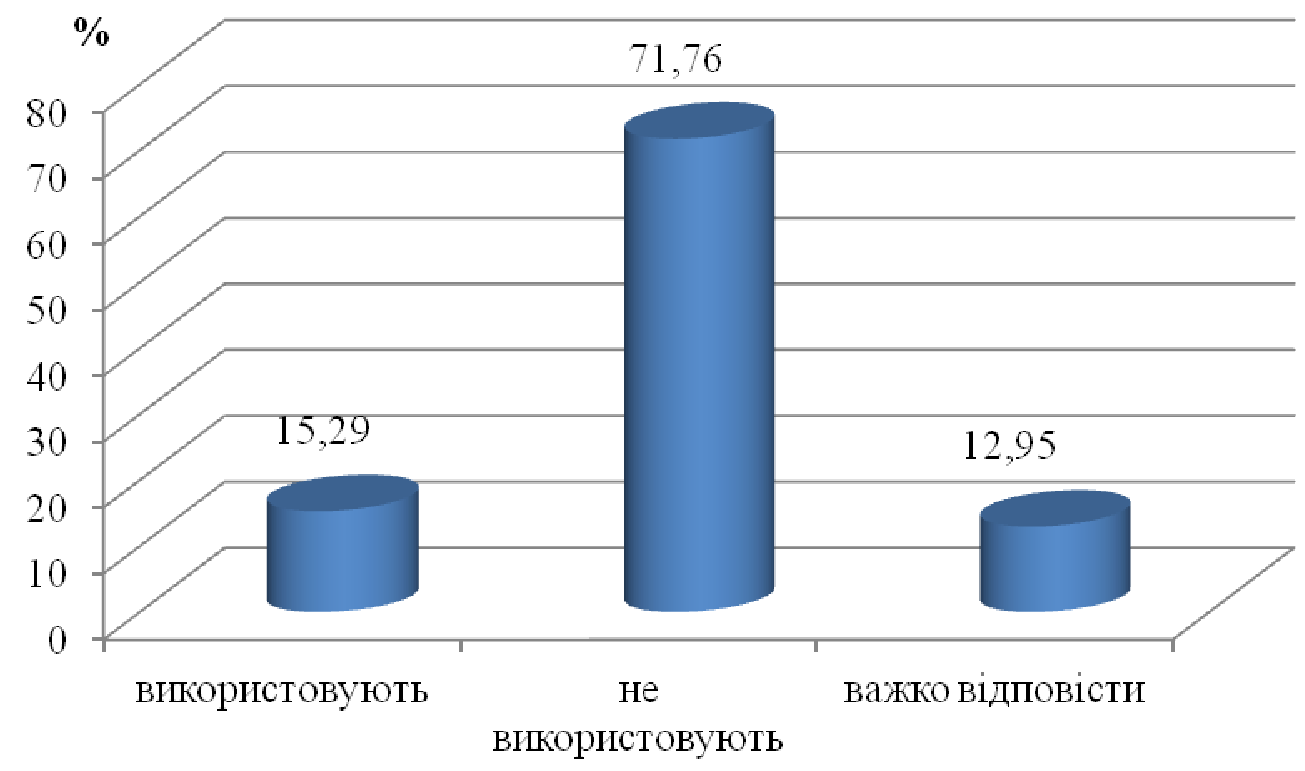

Рис. 1. Розподіл відповідей викладачів про використання віртуальних спільнот для підготовки бакалаврів з туризму до професійної взаємодії з клієнтами, \%

Упровадження нових способів i засобів навчання потребує розроблення відповідного наукового і навчально-методичного забезпечення. Отже, для нас було важливо з'ясувати, чи розробляють викладачі таке забезпечення для запровадження та підтримки функціонування віртуальних спільнот. Аналіз відповідей викладачів показав, що розробляють 8,69\%, опитаних; не розробляють - 65,95\% викладачів; важко відповісти - 25,36 \% респондентам.

Результати дослідження дозволили констатувати, що лише 12,95 \% викладачів вищих навчальних закладів використовують віртуальні спільноти для підготовки бакалаврів з туризму до професійної взаємодії зі споживачами туристичних послуг. Це зумовило створення нами Інтернет-клубу спілкування з клієнтами (рис. 2), що спонукає всіх учасників навчально-виховного процесу до набуття й удосконалення IКТ грамотності, професійної етики, комунікативних компетентностей тощо. 


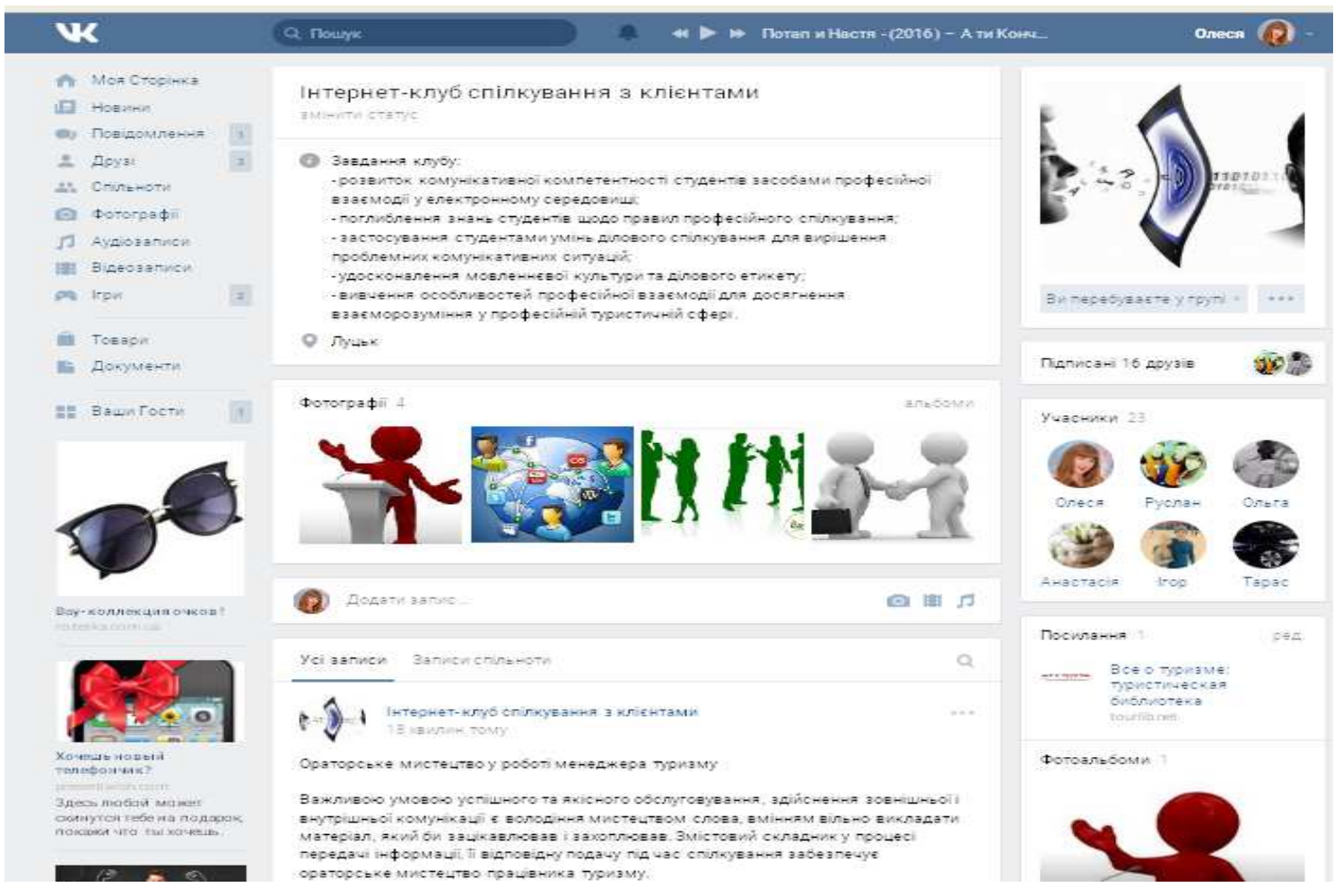

Рис. 2. Сторінка Інтернет-клубу спілкування з клієнтами

У межах дослідження проведено анкетування бакалаврів 3 туризму щодо актуальності створення Інтернет-клубу спілкування з клієнтами у соціальній мережі. Студентам було запропоновано обрати найбільш оптимальну соціальну мережу для створення інтернет-клубу. Результати опитування свідчать, що 60,43\% студентів надали перевагу соціальній мережі «ВКонтакті», 21,14 \% - «Facebook», 13,01 \% «Однокласники» і лише 5,42 \% запропонували інші ресурси (рис. 3).

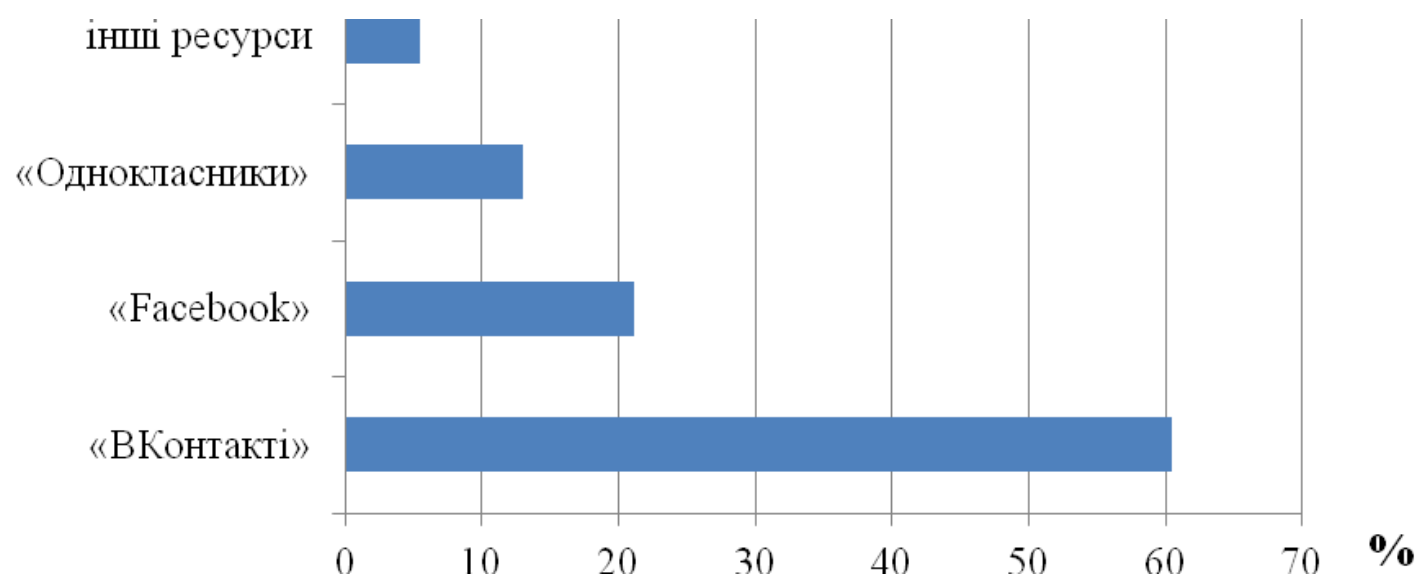

Рис. 3. Розподіл відповідей студентів щчодо вибору соџіальної мережі для створення інтернет-клубу, \%

Метою діяльності створеного нами у соціальній мережі «ВКонтакті» Інтернетклубу спілкування 3 клієнтами $€$ формування навичок спілкування як чинника 
професійної взаємодії з клієнтами. Учасниками клубу є студенти-туристи та інші користувачі мережі.

Відповідно до мети діяльності клубу передбачається вирішення таких завдань: розвиток комунікативної компетентності студентів засобами професійної взаємодії в електронному середовищі; поглиблення знань студентів щодо правил професійного спілкування; застосування студентами вмінь ділового спілкування для вирішення проблемних комунікативних ситуацій; удосконалення мовленнєвої культури та ділового етикету; вивчення особливостей професійної взаємодії для досягнення взаєморозуміння у професійній туристичній сфері. Для розв'язання цих завдань на сторінці клубу викладаються теоретичні матеріали, практичні поради, вправи, відеоматеріали тощо.

Отже, можна спрогнозувати, що Інтернет-клуб спілкування 3 клієнтами сприятиме підвищенню рівня комунікативної компетентності, особистісного й професійного спілкування та формуванню готовності бакалаврів 3 туризму до професійної взаємодії зі споживачами туристичних послуг, а також дозволить удосконалювати навички користування медіа-ресурсами. Віртуальні спільноти як форма активного навчання дозволяють перетворити захоплення, інтереси на професійну зацікавленість.

\section{5. ВИСНОВКИ ТА ПЕРСПЕКТИВИ ПОДАЛЬШИХ ДОСЛІДЖЕНЬ}

1. Аналіз наукових публікацій щодо впровадження віртуальних спільнот у навчальний процес показав, що як одна 3 навчальних форм вони успішно використовуються і досліджуються.

2. Упровадження у навчальний процес вищих навчальних закладів різноманітних інтернет-технологій сприяє розвитку інформаційної культури студентів і навичок професійної комунікації, що особливо актуально для студентів-туристів.

3. Опитування викладачів щодо використання віртуальних спільнот для підготовки бакалаврів з туризму до професійної взаємодії з клієнтами свідчить, що переважна більшість викладачів не застосовують цю форму спілкування у навчальному процесі.

4. Участь у віртуальних спільнотах навчального характеру за своєю суттю $є$ своєрідною імітацією професійної діяльності і фактором розвитку особистісних інтересів, а формат інтернет-клубу дозволяє якнайкраще поєднати ці два аспекти.

5. Створення і діяльність Інтернет-клубу спілкування 3 клієнтами має на меті підвищити ефективність професійної підготовки бакалаврів з туризму, розвиваючи їхні комунікативні компетентності, навички особистісного і професійного спілкування, а також уникати і розв'язувати проблеми взаємодії зі споживачами туристичних послуг.

6. Подальше вивчення проблеми використання віртуальних спільнот у процесі навчання студентів пов'язане 3 аналізом ефективності й актуальності матеріалів контенту й активності учасників.

\section{СПИСОК ВИКОРИСТАНИХ ДЖЕРЕЛ}

1. Готько О. Соціальні Інтернет-мережі та віртуалізація суспільного життя [Електронний ресурс] / О. Готько, О. Чайковська, Н. Наливайко. // Молодь і ринок. - №2 (133) - 2016. - С. 94-98. - Режим доступу http://irbis-nbuv.gov.ua/cgibin/irbis_nbuv/cgiirbis_64.exe?C21COM=2\&I21DBN=UJRN\&P21DBN=UJRN\&IMAGE_FILE_DOW NLOAD=1\&Image_file_name=PDF/Mir_2016_2_23.pdf. 
2. Іванюк І. В. Досвід віртуальних навчальних спільнот у формуванні полікультурної компетентності учнів: міжнародний аспект [Електронний ресурс] / I. В. Іванюк. - Режим доступу : http://lib.iitta.gov.ua/1066/1/віртуальні_спільноти.pdf.

3. Малицька I. Д. Віртуальні освітні спільноти як ефективний засіб формування IКТкомпетентностей: зарубіжний досвід [Електронний ресурс] / I. Д. Малицька // Інформаційні технології і засоби навчання. - 2013. - № 6 (38). - Режим доступу : http://journal.iitta.gov.ua/index.php/itlt/article/download/956/708.

4. Моисеева М. Феномен виртуальных учебных сообществ [Электронный ресурс] / М. Моисеева, С. Сойферт. - - Режим доступа http://emag.iis.ru/arc/infosoc/emag.nsf/BPA/b6bfbf5f9b5ab471c3256c5200340dc9.

5. Фещенко А. В. Социальные сети в образовании: анализ опыта и перспективы развития/ А. В. Фещенко // Открытое дистанционное образование. - №3 (43).- Томск : ТГУ АСОУ, 2011. C. 44-49.

6. Ala-Mutka K. Learning in Informal Online Networks and Communities / K. Ala-Mutka // Luxembourg : Office for Official Publications of the European Communities, 2010. - 88 p.

7. Brusilovsky, P. Domain, Task, and User Models for an Adaptive Hypermedia Performance Support System/ P. Brusilovsky, D. W. Cooper // Proc. of 2002 International Conference on Intelligent User Interfaces, San Francisco, CA, ACM Press 23-30.

8. Brusilovsky, P. Layered evaluation of adaptive learning systems / P. Brusilovsky, C. Karagiannidis, D. G. Sampson // Int. J. of Continuing Engineering Education and Lifelong Learning. - 2004. - Vol. 14, № 4/5 - P. 402-21.

9. Encyclopedia Britannica. Virtual community [Електронний pecypc]. — Режим доступу: http://www.britannica.com/EBchecked/topic/1495829/virtual-community.

10. Mary Meeker. Takes Youon a Tourofthe 2015 Internet Trends Report. [Електронний ресурс]. - Режим доступу : http://recode.net/.

11. Wegener R. Virtual Learning Communities: Success Factors and Challenges / R. Wegener, J. M. Leimeister // International Journal of Technology Enhanced Learning (IJTEL). - 2012. - Number : 5/6, Vol. 4. - P. 383-397.

\title{
ИСПОЛЬЗОВАНИЕ ВИРТУАЛЬНЫХ СООБЩЕСТВ ДЛЯ ПОДГОТОВКИ БАКАЛАВРОВ ТУРИЗМА К ПРОФЕССИОНАЛЬНОМУ ВЗАИМОДЕЙСТВИЮ С ПОТРЕБИТЕЛЯМИ ТУРИСТИЧЕСКИХ УСЛУГ
}

\author{
Дышко Олеся Леонидовна \\ кандидат педагогических наук, доцент кафедры туризма \\ ЧВУЗ «Академия рекреационных технологий и права», г. Луцк, Украина \\ olesya.dyshko16@gmail.com
}

\begin{abstract}
Аннотация. В статье анализируется система взглядов на проблему подготовки специалистов для сферы туризма к профессиональному взаимодействию с потребителями туристических услуг с помощью сообществ в глобальных коммуникационных сетях. Приведены результаты анкетирования преподавателей об использовании виртуальных сообществ для подготовки бакалавров туризма к профессиональному взаимодействию с потребителями туристических услуг. Представлены результаты опроса студентов-туристов об эффективности использования социальных сетей в процессе обучения. Обоснована целесообразность создания Интернет-клуба общения с клиентами для практической подготовки будущих специалистов к профессиональному взаимодействию с потребителями туристических услуг.
\end{abstract}

Ключевые слова: бакалавры туризма; виртуальное сообщество; потребители туристических услуг; Интернет-клуб общения с клиентами. 


\title{
THE USE OF VIRTUAL COMMUNITIES FOR FORMATION THE READINESS OF BACHELORS OF TOURISM TO PROFESSIONAL INTERACTION WITH CONSUMERS OF TOURISM SERVICES
}

\author{
Olesia L. Dyshko \\ $\mathrm{PhD}$ (in Pedagogical Sciences), assistant professor of Tourism \\ Private higher educational establishment «Academy of Recreational Technologies and Law», Lutsk, Ukraine \\ olesya.dyshko16@gmail.com
}

\begin{abstract}
The system of views on the problem of training specialists of Tourism to professional interaction with consumers of tourist services using communities global communicative networks are discussed in this article. The results of the survey of teachers about the usage of virtual communities for formation the readiness of Bachelors of Tourism to professional interaction with consumers of tourist services are given. The results of a survey of Tourism students about the use of social networks in educational activities are also represented in this article. The feasibility of establishing the Internet club to communicate with customers for forming the readiness of Bachelors of Tourism to professional interaction with consumers of tourism services is proved.
\end{abstract}

Keywords: Bachelors of Tourism; virtual community; consumers of tourism services; Internet club of communication with customers.

\section{REFERENCES (TRANSLATED AND TRANSLITERATED)}

1. Hotko O. Internet and social work virtualization [online] / O. Hotko, O. Chaikovska, N. Nalyvaiko // Molod i rynok. - №2 (133) - 2016. - P. 94-98. - Available from : http://irbis-nbuv.gov.ua/cgibin/irbis_nbuv/cgiirbis_64.exe?C21COM=2\&I21DBN=UJRN\&P21DBN=UJRN\&IMAGE_FILE_DOW NLOAD=1\&Image_file_name=PDF/Mir_2016_2_23.pdf (In Ukrainian).

2. Ivaniuk I. V. Virtual learning communities experiences in the formation of multicultural competence of students: international aspects [online] / I. V. Ivaniuk. - Available from : http://lib.iitta.gov.ua/1066/1/віртуальні_спільноти.pdf (In Ukrainian).

3. Malytska I. D. Virtual educational community as an effective mean of ICT-competence formation [online] / I. D. Malytska // Ihformatsiini tekhnolohii i zasoby navhannia. - 2013. - № 6 (38). Available from : http://journal.iitta.gov.ua/index.php/itlt/article/download/956/708 (In Ukrainian).

4. Moisieeva M. Phenomenon of virtual educational communities [online] / M. Moisieeva. - Available from: http://emag.iis.ru/arc/infosoc/emag.nsf/BPA/b6bfbf5f9b5ab471c3256c5200340dc9 (in Russian).

5. Feshhenko A. V. Social networks in education: analysis of the experience and perspectives of development / A. V. Feshhenko // Open Distance Education. - №3 (43).- Tomsk: TSUASEU, 2011. - P. 44-49 (in Russian).

6. Ala-Mutka, K. Learning in informal online networks and communities [online] / K. Ala-Mutka. Retrieved from : $\quad$ http://www.icde.org/filestore/News/20042010/2010/PedagogicalInnovationsinNewLearningCommunities.pdf (in English).

7. Brusilovsky, P. Domain, Task, and User Models for an Adaptive Hypermedia Performance Support System / Brusilovsky, P., Cooper, D. W. // Proc. of 2002 International Conference on Intelligent User Interfaces, San Francisco, CA, ACM Press 23-30 (in English).

8. Brusilovsky, P. Layered evaluation of adaptive learning systems / P. Brusilovsky, C. Karagiannidis, D. G. Sampson // Int. J. of Continuing Engineering Education and Lifelong Learning. - 2004. - Vol. 14, № 4/5 - P. 402-421 (in English).

9. Encyclopedia Britannica. Virtual community [online]. - Available from: http://www.britannica.com/EBchecked/topic/1495829/virtual-community (in English).

10. Mary Meeker. Takes Youon a Tourofthe 2015 Internet Trends Report / Mary Meeker. - Available from: http://recode.net/ (in English).

11. Wegener, R. \& Leimeister, J. M. Virtual Learning Communities: Success Factors and Challenges. In: International Journal of Technology Enhanced Learning (IJTEL). Erscheinungsjahr/Year: Seiten/Pages: 2012. - Number : 5/6, Vol. 4. - P. 383-397 (in English).

\section{$(\mathrm{CC}) \mathrm{EY}$-NC-SA}

This work is licensed under Creative Commons Attribution-NonCommercial-ShareAlike 4.0 International License. 